\title{
Identification of the nonribosomal peptide synthetase gene responsible for bassianolide synthesis in wood-decaying fungus Xylaria sp. BCC1067
}

\begin{abstract}
Correspondence
Supapon Cheevadhanarak supaponche@gmail.com
\end{abstract}

Received 11 October 2007

Revised 2 January 2008

Accepted 3 January 2008

\author{
Jiraporn Jirakkakul, ${ }^{1}$ Juntira Punya, ${ }^{2}$ Somchai Pongpattanakitshote, ${ }^{2}$ \\ Porntip Paungmoung, ${ }^{1}$ Namol Vorapreeda, ${ }^{1}$ Anuwat Tachaleat, ${ }^{1}$ \\ Cheeranun Klomnara, ${ }^{1}$ Morakot Tanticharoen ${ }^{2}$ \\ and Supapon Cheevadhanarak ${ }^{1,3}$
${ }^{1}$ School of Bioresources and Technology, King Mongkut's University of Technology Thonburi, Bangkok 10140, Thailand
${ }^{2}$ National Center for Genetic Engineering and Biotechnology, Thailand Science Park, 113 Paholyothin Road, Klong 1, Klong Luang, Pathumthani 12120, Thailand
${ }^{3}$ Pilot Plant Development and Training Institute, King Mongkut's University of Technology Thonburi, Bangkok 10150, Thailand

\begin{abstract}
Intensive study of gene diversity of bioactive compounds in a wood-rot fungus, Xylaria sp. BCC1067, has made it possible to identify polyketides and nonribosomal peptides (NRPs) unaccounted for by conventional chemical screening methods. Here we report the complete nonribosomal peptide synthetase (NRPS) gene responsible for the biosynthesis of an NRP, bassianolide, using a genetic approach. Isolation of the bassianolide biosynthetic gene, nrpsxy, was achieved using degenerate primers specific to the adenylation domain of NRPS. The complete ORF of nrpsxy is $10.6 \mathrm{~kb}$ in length. Based on comparisons with other known NRPSs, the domain arrangement of NRPSXY is most likely to be C-A-T-C-A-M-T-T-C-R. The other ORF found upstream of nrpsxy, designated ef $x y$, is $1.8 \mathrm{~kb}$ in length and shows high similarity to members of the major facilitator superfamily of transporters. Functional analysis of the nrpsxy gene was conducted by gene disruption, and the missing metabolite in the mutant was identified. Chemical analysis revealed the structure of the metabolite to be a cyclooctadepsipeptide, bassianolide, which has been found in other fungi. A bioassay of bassianolide revealed a wide range of biological activities other than insecticidal uses, which have been previously reported, thus making bassianolide an interesting candidate for future structural modification. This study is the first evidence for a gene involved in the biosynthesis of bassianolide.
\end{abstract}

Abbreviations: ESITOF, electrospray ionization-time of flight; ESYN, enniatin synthetase; HTS, HC-toxin synthetase; KPR, ketopantoate reductase; MFS, major facilitator superfamily; NRP, nonribosomal peptide; NRPS, nonribosomal peptide synthetase.

The GenBank/EMBL/DDBJ accession numbers for the nrpsxy and efxy sequences of Xylaria sp. BCC1067 are EF456733 and EF456734, respectively.

A supplementary table showing ${ }^{13} \mathrm{C}$ NMR data for substance $\mathrm{A}$ in $\mathrm{CDCl}_{3}$, and three supplementary figures showing ${ }^{1} \mathrm{H}$ NMR and ${ }^{13} \mathrm{C} N M R$ spectra of the substance A molecule purified from Xylaria sp. BCC1067 in $\mathrm{CDCl}_{3}$ solution, ESITOF MS data for substance $\mathrm{A}$, and an HPLC chromatogram of the acid hydrolysate of substance $A$, are available with the online version of this paper.

\section{INTRODUCTION}

Bassianolide is an octacyclodepsipeptide consisting of four molecules each of D-hydroxyisovaleric acid and L- $N$ methylleucine, and has been reported to be an insecticide obtained from Beauveria bassiana and Verticillium lecanii (Suzuki et al., 1977). The structure of bassianolide is shown in Fig. 1. Bassianolide belongs to a family of structurally related cyclodepsipeptide compounds, which have emerged as a broad family of compounds characterized by at least one ester linkage. Great interest in this class of natural products has stemmed from their diverse range of biological activities, as has been shown for cryptophycins, didemnins, dolastatins, PF1022, enniatin, destruxin, 


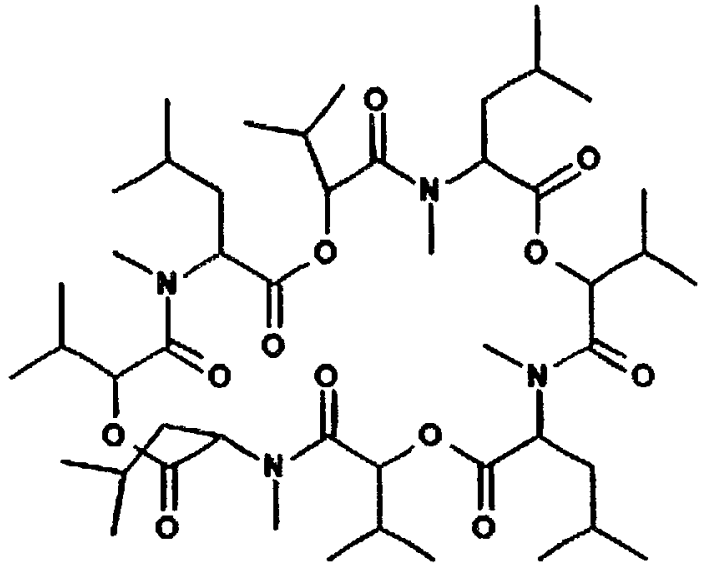

Fig. 1. Structure of bassianolide. The structure was obtained from PubChem Compound (http://www.ncbi.nlm.nih.gov/sites/ entrez?db=pccompound).

beauvericin and valinomycin (Scherkenbeck et al., 2002; Sarabia et al., 2004).

Cyclodepsipeptides are not synthesized by ribosomes in the same way as general peptides, but are instead produced by a nonribosomal peptide synthetase (NRPS). NRPSs are multimodular enzymes in which each module is responsible for the addition of a single amino acid. These enzymes produce nonribosomal peptides (NRPs) by a thiotemplate mechanism. NRPSs can incorporate proteinogenic and non-protein amino acids, as well as carboxy and hydroxy acids. Further modifications, such as $N$-methylation, epimerization, cyclization and heterocyclic ring formation, can also be carried out by these enzymes (von Döhren et al., 1997; Marahiel et al., 1997; Mootz et al., 2002).

NRPs occur in a wide range of organisms, including bacteria, fungi, plants and marine organisms (Keller \& Schauwecker, 2003). These compounds often possess desirable pharmaceutical characteristics, and have thus been used for many applications, including use as siderophores, antibiotics, immunosuppressants and anticancer drugs (Konz \& Marahiel, 1999; von Döhren \& Grafe, 1997).

So far, the majority of NRPSs and their products have been characterized in bacteria, especially Bacillus and Streptomyces species. Fewer fungal genes encoding NRPS have been fully sequenced and characterized experimentally. These genes include acvA from Aspergillus nidulans and Penicillium chrysogenum, which controls the production of the precursor of $\beta$-lactam antibiotics such as penicillin (Brakhage, 1997); simA from Tolypocladium inflatum, which controls the production of cyclosporin A and is used as an immunosuppressive drug in organ transplant surgery (Weber et al., 1994); and sidA, which controls production of the siderophores $N^{\prime}, N^{\prime}, N^{\prime \prime \prime}$ triacetylfusarinine $\mathrm{C}$ (TAF) and ferricrocin, which are virulence factors in Aspergillus fumigatus (Hissen et al., 2005). To date, the genomic sequences of fungi appear to have the potential for faster discovery of novel NRPS genes. For example, 12 NPRS genes have been found in the Cochliobolus heterostrophus genome (Lee et al., 2005); 15 putative NRPS genes have been found in Fusarium graminearum (Tobiasen et al., 2007); and 14, 22, 14, 20 and 18 NRPS genes have been found in the genome sequences of A. fumigatus, Aspergillus terreus, A. nidulans, Aspergillus flavus and Aspergillus oryzae, respectively (Cramer et al., 2006a). The functions of some genes have been determined by gene disruption; for instance, NPS6 from $C$. heterostrophus is involved in virulence and tolerance to oxidative stress (Lee et al., 2005; Oide et al., 2006), and gliP from A. fumigatus is involved in gliotoxin production (Cramer et al., 2006b). However, the functions of most NRPS genes in fungi remain unknown, requiring further investigation for greater understanding of NRPSs in these organisms (Stack et al., 2007).

Xylaria sp. BCC1067 has been reported to be a rich source of bioactive secondary metabolites (Isaka et al., 2000). One of the major compounds, 19,20-epoxycytochalasin Q, has revealed an interesting characteristic, as it contains polyketide and an amino acid in its core structure (hybrid polyketide-NRP). From our search for additional polyketide synthases (PKSs) and NRPSs in this fungus using a genetic approach via PCR, at least 10 PKS, one hybrid PKS-NRPS (Amnuaykanjanasin et al., 2005) and seven NRPS (Paungmoung et al., 2007) genes were found. These results implied that Xylaria sp. BCC1067 should have the genetic capacity to produce a number of natural products and that the total amount of these compounds is likely to be much greater than that which has already been reported for this fungus.

In this study, we identified and analysed the complete sequence of the bassianolide synthetase gene, nrpsxy, and confirmed its role in bassianolide biosynthesis by insertional mutagenesis, as shown by the absence of bassianolide production following disruption of the nrpsxy locus in Xylaria sp. BCC1067. Moreover, an ORF upstream of nrpsxy was also identified, revealing high similarity to members of the major facilitator superfamily (MFS) of transporters.

\section{METHODS}

Media and strains. Xylaria sp. BCC1067 (wild-type) and transformants of this strain were kept on malt extract agar (MEA) at $25{ }^{\circ} \mathrm{C}$. Seven-day-old culture agar discs ( $3 \mathrm{~mm}$ diameter) of either the wildtype or the mutant strain were inoculated into $50 \mathrm{ml}$ malt extract broth (Oxoid) for 14 days, before harvesting for DNA isolation. Escherichia coli LE392 was used as the host for lambda Fix II genomic library construction. Subclones were propagated in E. coli strain DH5 $\alpha$ (Woodcock et al., 1989).

Construction of a lambda genomic DNA library. A genomic DNA from Xylaria sp. BCC1067 was prepared according to the method of Raeder \& Broda (1985). The genomic library of Xylaria sp. BCC1067 
was constructed following the protocol for Gigapack III XL Packaging Extract provided by the manufacturer (Stratagene).

Identification, cloning and sequencing of an NRPS gene. Degenerate oligonucleotide primers targeting highly conserved motifs of known NRPSs (Turgay \& Marahiel, 1994) were used for amplification and identification by PCR of putative NRPS gene fragments in Xylaria sp. BCC1067. The sequences of the oligonucleotides used were as follows: forward primer $\mathrm{A} 3,5^{\prime}-\mathrm{TA}(\mathrm{C} / \mathrm{T}) \mathrm{AC}(\mathrm{T} / \mathrm{C} /$ G) TC(A/T/C) GGI (A/T)CI AA(G/A) GC-3'; and reverse primer A5, $5^{\prime}-(\mathrm{C} / \mathrm{T}) \mathrm{TC}(\mathrm{T} / \mathrm{C} / \mathrm{G}) \mathrm{GT}$ IGG (T/C/G)CC (A/G)TA (T/G)GC-3'. The NRPS PCR product $\left(\mathrm{EN}_{11}\right)$ labelled with $\left[{ }^{32} \mathrm{P}\right] \mathrm{dATP}$ was used as a probe for screening the genomic library of Xylaria sp. BCC1067 by plaque hybridization.

Construction of a bassianolide-deficient Xylaria sp. BCC1067 mutant. Disruption of the nrpsxy gene was achieved by inserting a $2.05 \mathrm{~kb}$ phleomycin-resistance cassette (ble), which was derived from the vector pOBT (Cheevadhanarak et al., 1991), into the first adenylation domain-coding region. The disruption construct was created by cloning a HincII fragment of the nrpsxy gene from the DNA insert of lambda 2 XyENRPS I into vector pUC18. The resulting plasmid pEN3.8 was inserted by ble cassette into an SmaI site corresponding to the adenylation domain of the cloned fragment; as a result, a new plasmid, pDEN3.8, was obtained. The disruption plasmid pDEN3.8 was then cut with EcoRI to obtain a linear $4.554 \mathrm{~kb}$ DNA fragment. This fragment contained 1.048 and $1.451 \mathrm{~kb}$ segments of the nrpsxy gene flanking the ble cassette (Fig. 3a) and was used to transform protoplasts of Xylaria sp. BCC1067 according to the method of Tilburn et al. (1983).

Substrate specificity of the adenylation domain prediction. The substrate specificity-conferring amino acid in the adenylation domains was determined according to the method of Stachelhaus et al. (1999)

HPLC analysis of metabolite profile. HPLC was conducted using a reverse-phase column (Inertsil ODS-3, GL Sciences) and diode array detector (996 Photodiode Array Detector, Waters). An isolated culture of either the Xylaria sp. BCC1067 wild-type or the mutant NTT4 was grown in $250 \mathrm{ml}$ malt extract broth. The cultures were incubated at $25{ }^{\circ} \mathrm{C}$ for 14 days. Subsequently, the harvested mycelia were extracted with $50 \mathrm{ml}$ methanol for 2 days. After discarding the mycelium, the lipid portion of the extract was removed by extraction with $30 \mathrm{ml}$ hexane, and the methanol layer was concentrated under reduced pressure to obtain a brown semisolid. This mycelial extract was dissolved in methanol to a final concentration of $100 \mathrm{mg} \mathrm{ml}^{-1}$. Separation of metabolites from $20 \mu \mathrm{l}$ of extract was performed on an Inertsil ODS-3 reverse-phase column. Analysis was done at a flow rate of $1 \mathrm{ml} \mathrm{min}{ }^{-1}$ at $210 \mathrm{~nm}$ with a water-acetonitrile step gradient as follows: $0 \mathrm{~min} / 5 \%$ acetonitrile, $10 \mathrm{~min} / 5 \%$ acetonitrile, $15 \mathrm{~min} / 50 \%$ acetonitrile, $25 \mathrm{~min} / 50 \%$ acetonitrile, $30 \mathrm{~min} / 80 \%$ acetonitrile, $40 \mathrm{~min} / 80 \%$ acetonitrile, $45 \mathrm{~min} / 100 \%$ acetonitrile, and $60 \mathrm{~min} /$ $100 \%$ acetonitrile, following the method of Weckwerth et al. (2000). The water used in the analysis contained $0.05 \%(\mathrm{v} / \mathrm{v})$ trifluoroacetic acid (TFA).

Isolation and characterization of pure substance $\mathbf{A}$. The mycelial extract was fractionated by Sephadex LH20 column chromatography (using methanol as an eluent) in order to obtain the fraction containing substance A. Subsequently, substance A was purified by step-gradient HPLC, as described above. Structural documentation was performed by NMR and MS analysis. Proton NMR $\left({ }^{1} \mathrm{H}\right.$ NMR) and carbon-13 NMR $\left({ }^{13} \mathrm{C} \mathrm{NMR}\right)$ spectra were measured in $\mathrm{CDCl}_{3}$ on a Bruker DRX400 spectrometer, and electrospray ionization-time of flight (ESITOF) mass spectra were obtained on a Micromass LCT mass spectrometer (Isaka et al., 2005).
Determination of $D$ and $L$ configuration of amino acids in substance A by acid hydrolysis. Substance A $(0.5 \mathrm{mg})$ was hydrolysed with $6 \mathrm{M} \mathrm{HCL}(0.4 \mathrm{ml})$ at $110-120{ }^{\circ} \mathrm{C}$ for $15 \mathrm{~h}$. After concentration to dryness, the residue was dissolved in $100 \mu \mathrm{l}$ methanol. Twenty microlitres of hydrolysed substance A was subjected to HPLC using a ligand-exchange-type chiral column (SUMICHIRAL OA-5000, $5 \mu \mathrm{m}$ bead size, $4.6 \times 150 \mathrm{~mm}$ internal diameter $\times$ length; Sumika Chemical Analysis Service) with $5 \%$ $\mathrm{CH}_{3} \mathrm{OH}$ in $2 \mathrm{mM} \mathrm{CuSO}_{4}$ as the system eluent (flow rate $1 \mathrm{ml} \mathrm{min}^{-1}$, UV wavelength $235 \mathrm{~nm}$ ). D and L configurations of $\alpha$-hydroxyisovaleric acid and $N$-methylleucine were used as reference standards.

Biological assay. Biological activities of substance $\mathrm{A}$ against human epidermoid carcinoma (KB cells), human breast cancer (BC-1 cells), human small cell lung cancer (NCI-H187 cells), Mycobacterium tuberculosis H37Ra, Plasmodium falciparum K1, and African Green Monkey kidney fibroblasts (Vero cells) were performed by the Bioassay Laboratory at the National Center for Genetic Engineering and Biotechnology (BIOTEC), Thailand. Antibacterial activity was assessed using the disc diffusion assay (McGaw et al., 2000). The bacterial strains tested included Staphylococcus aureus ATCC 29213, Bacillus subtilis ATCC 6633, E. coli ATCC 25922 and Pseudomonas aeruginosa ATCC 27853.

\section{RESULTS}

\section{Identification of the NRPS gene}

To identify the NRPS gene(s) in Xylaria sp. BCC1067, degenerate PCR primers specific to conserved sequence motifs of NRPS genes were used in the amplification of genomic DNA from Xylaria sp. BCC1067. One product ( $\sim 400 \mathrm{bp}), \mathrm{EN}_{11}$, showed the highly conserved core motifs A3-A5 of typical NRPS adenylation domains. Probing the genomic library of Xylaria sp. BCC1067 with $\mathrm{EN}_{11}$ allowed us to identify two overlapping phages, $\lambda$ XyENRPS I and 2XyEN9.1, which covered $7.24 \mathrm{~kb}$ corresponding to a partial NRPS gene lacking its $3^{\prime}$-terminal region. To identify the remaining part of this gene, an additional step of chromosomal walking was performed. A SalI fragment of the 3 '-terminal end of $\lambda$ XyEN9.1, namely $\mathrm{EN}_{643}$, was used as a probe to screen the genomic library (Fig. 2a). One positive phage, $\lambda \mathrm{EN} 643 \mathrm{~T} 113$, was isolated, and its DNA insert was subjected to sequencing. The results of sequence analysis revealed a complete ORF (10641 bp), designated nrpsxy, which was interposed by a $61 \mathrm{bp}$ intron located near the $3^{\prime}$ end. In addition, we also found a smaller complete ORF (1806 bp), designated $e f x y, 5.7 \mathrm{~kb}$ upstream of $n r p s x y$, which was transcribed in the opposite direction.

By sequence analysis, we deduced that the nrpsxy gene encoded a single ORF of two complete peptide synthetase modules and an additional domain homologous to ketopantoate reductase (KPR) at the $\mathrm{C}$ terminus of the predicted protein (Fig. 2b). The predicted protein encoded by the nrpsxy gene contained 3546 amino acids with a calculated molecular mass of about $390 \mathrm{kDa}$. Almost the entire length of the amino acid sequence of NRPSXY (amino acid position 1-3135) displayed strong homology 
(a)

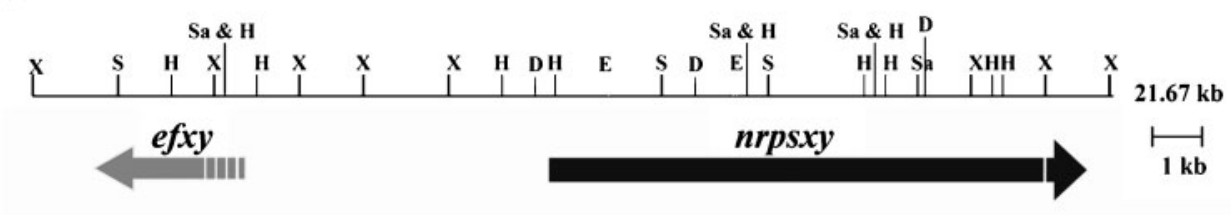

$\lambda$ XyENRPS I

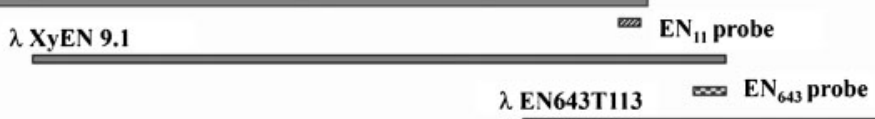

(b)

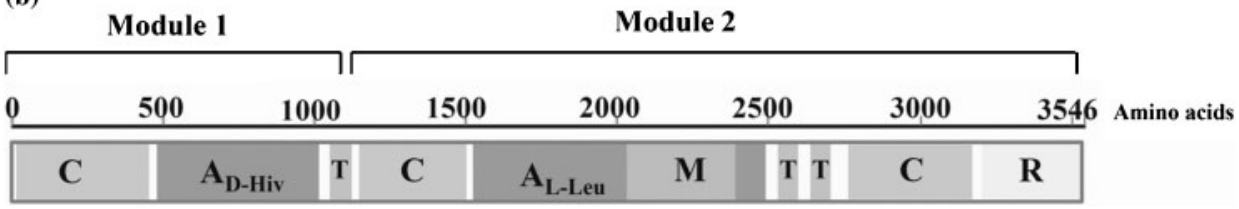

Fig. 2. Schematic map of the genomic region containing the nrpsxy gene and modular structure of NRPSXY. (a) Restriction map and gene arrangement of efxy (GenBank accession no. EF456734) and nrpsxy (GenBank accession no. EF456733) in Xylaria sp. BCC1067. Restriction site abbreviations: D, Dral; E, EcoRl; H, Hincll; S, Smal; Sa, Sall; X, Xbal. The orientations of the genes are indicated by arrowheads, and the positions of introns are indicated by white bars. The nrpsxy gene is interrupted by a putative intron of $61 \mathrm{bp}$. The lambda clone arrangements isolated in this work and the probes used for chromosomal walking are marked $\left(\mathrm{EN}_{11}, \mathrm{EN}_{643}\right)$. (b) Modular organization of NRPSXY as revealed by cDART (conserved Domain Architecture Retrieval Tool; http://www.ncbi.nlm.nih.gov/Structure/lexington/lexington.cgi?cmd=rps) from NCBI. The domains within the modules are indicated: $\mathrm{A}$, adenylation domain; $\mathrm{C}$, condensation domain; $\mathrm{T}$, thiolation domain; $\mathrm{M}, \mathrm{N}$-methylation domain; $\mathrm{R}, \mathrm{KPR}$

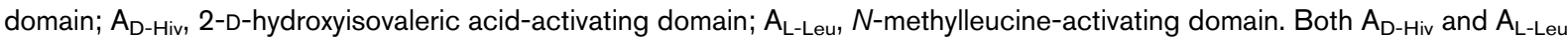
are annotated from the structure identification of substance $\mathrm{A}$ encoded by the nrpsxy gene.

to the enniatin synthetase (ESYN) encoded by the esyn gene of Fusarium equiseti (Q00869; $58 \%$ identity and 74\% similarity) and to the cyclosporin synthetase encoded by the simA gene of $T$. inflatum (CAA82227; $48 \%$ identity and $64 \%$ similarity). The C-terminal domain of about 412 amino acids (position 3136-3546) did not show any homology to known NRPSs in the databases, but displayed significant similarity to several uncharacterized proteins from various microbes, including KPRs such as AbpA_C of Magnaporthe grisea 70-15 (XP_363700; $45 \%$ identity and $66 \%$ similarity), AbpA of Pichia guilliermondii ATCC 6260 (XP_001483630; $29 \%$ identity and 50\% similarity), AbpA of Ps. aeruginosa C3719 (ZP_00965349; $30 \%$ identity and $46 \%$ similarity) and AbpA of E. coli F11 (ZP_00722740; $25 \%$ identity and $42 \%$ similarity). Detailed analysis of NRPSXY showed that it had a domain architecture (C-AT-C-A-M-T-T-C-R) with corresponding regions of condensation (C) in amino acid residues 48-432, 1104-1442 and 2719-3082; adenylation (A) in amino acid residues 505-982 and 1582-2482; $N$-methylation (M) in amino acid residues 2083-2399, where this domain was inserted into the adenylation domain within the second module (between motifs A8 and A9); and thiolation ( $\mathrm{T}$ ) in amino acid residues 1017-1082, 2510-2571 and 2608-2670, as well as a KPR (R) domain in amino acid residues $3174-$ 3507 , which contained a putative NAD/FAD binding motif
(SRIHILGVGNLGKFV) (Fig. 2b). These conserved residues are indicated in bold type in Table 1.

To predict the substrate specificity-conferring amino acid in the NRPSXY adenylation domains, two alternative methods were used: (1) BLAST analysis of the amino acid sequence of each A domain against protein databases; and (2) signature sequence analysis according to the method of Stachelhaus et al. (1999). When using BLAST analysis via the NCBI website (http://www.ncbi.nlm.nih.gov/blast/ Blast.cgi), the first A domain of NRPSXY showed homology to the D-2-hydroxyisovaleric acid-activating domain from ESYN of $F$. equiseti $(68 \%$ identity and $81 \%$ similarity), and the L-alanine-activating domain from HC-toxin synthetase (HTS) of Cochliobolus carbonum ( $38 \%$ identity and $58 \%$ similarity). The second A domain showed homology to the leucine-activating domain $(63 \%$ identity and $77 \%$ similarity) and to the valine-activating domain (59\% identity and $77 \%$ similarity) from cyclosporin synthetase of T. inflatum. It also showed homology to the valine-activating domain from ESYN of $F$. equiseti (54\% identity and $71 \%$ similarity) and from cereulide synthetase B (CesB) of Bacillus cereus (38\% identity and $56 \%$ similarity). However, the results from the second method revealed that the signature sequence of the first A domain showed significant matches to the signature 


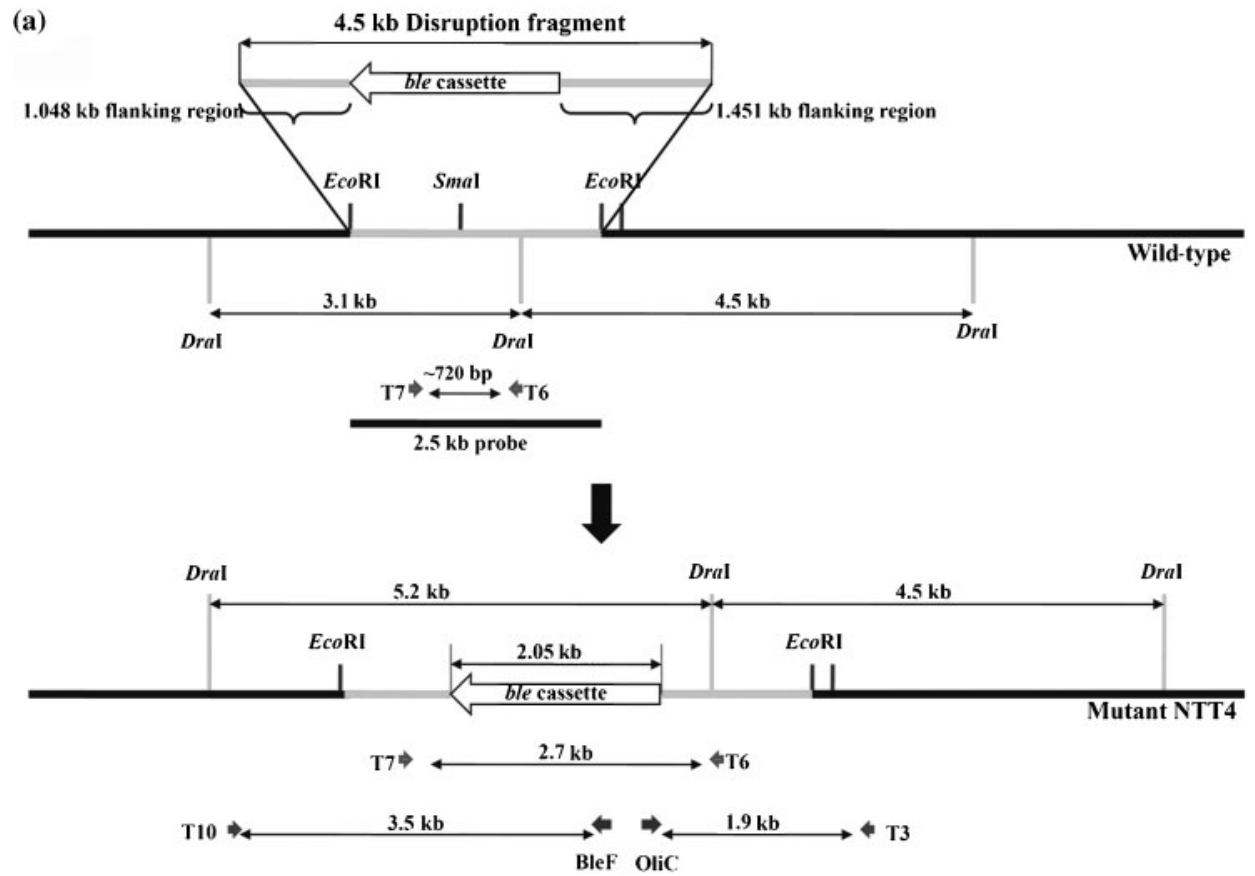

(b)

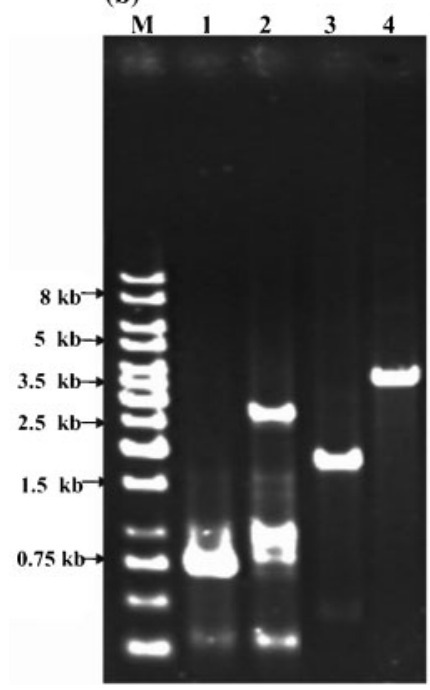

(c)

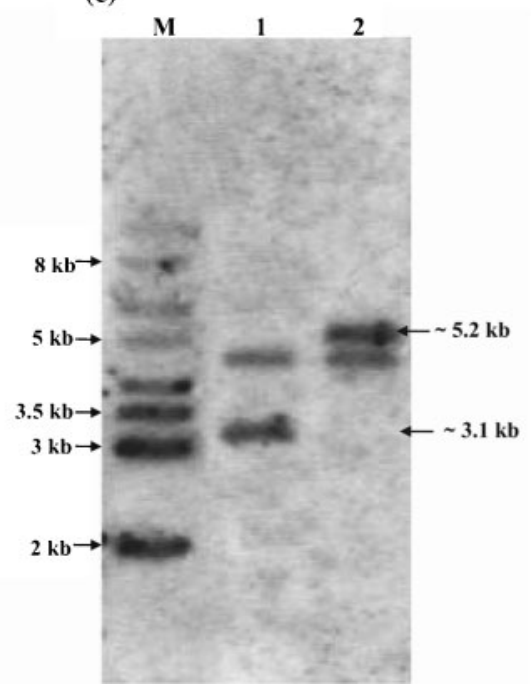

Fig. 3. Disruption of the gene encoding NRPSXY in Xylaria sp. BCC1067. (a) Schematic diagram of the insertion mutation of the nrpsxy gene. The disruption fragment, the genotype of the wild-type and the genomic rearrangement after a successful gene insertion by double-crossover integration in the mutant NTT4 are shown. The arrows marked with T6, T7, T10, T3, OliC and BleF represent the primers used for verifying the presence of the insertion in the mutant via PCR amplification. (b) PCR analysis of the mutant NTT4. Amplification of genomic DNA from the mutant NTT4 with the T6+T7 primer pair generated a PCR product of $\sim 2.7 \mathrm{~kb}$ (lane 2) compared to the undisrupted size from wild-type genomic DNA (lane 1). OliC + T3 and T10+BleF primer pairs showed PCR products of the predicted sizes $\sim 1.9$ (lane 3) and $\sim 3.5 \mathrm{~kb}$ (lane 4), which were absent when amplified from wildtype genomic DNA. The DNA ladder marker (lane M) shows the size in kilobases. (c) Southern blot analysis of the mutant NTT4. Dral-digested genomic DNA of the wild-type (lane 1) and the mutant NTT4 (lane 2) was hybridized to a $2.5 \mathrm{~kb}$ probe located at the $5^{\prime}$ end of the gene. A homologous crossover into the Dral fragment yielded a band of $\sim 5.2 \mathrm{~kb}$ and absence of the $3.1 \mathrm{~kb}$ wild-type band, as seen in mutant NTT4, indicating ble cassette insertion into the nrpsxy gene. Lane M, DNA ladder marker.

sequence for D-2-hydroxyisovaleric acid of ESYN (90\%) and to L-alanine of HTS (20\%). The signature sequence for the second domain of NRPSXY revealed the highest similarity to the $\mathrm{N}$-methylleucine-activating domain found in the second module of cyclosporin synthetase (CssA) ( $90 \%)$, the $\mathrm{N}$-methylvaline-activating domain found in the 
Table 1. Comparison of the conserved motifs of the catalytic NRPSXY domains with conserved core motifs previously defined by Konz \& Marahiel (1999)

Conserved residues are indicated in bold type. ND, Not detected.

\begin{tabular}{|c|c|c|c|c|}
\hline Domain & $\begin{array}{c}\text { Consensus sequence } \\
\text { (Konz \& Marahiel, 1999) }\end{array}$ & $\begin{array}{l}\text { NRPSXY module } 1 \\
\text { (this work) }\end{array}$ & \multicolumn{2}{|c|}{ NRPSXY module 2 (this work) } \\
\hline \multicolumn{5}{|l|}{ Adenylation } \\
\hline A1 & L(TS)YxEL & WTYNEL & LTYAEL & \\
\hline A2 (core 1$)$ & LKAGxAYL(VL)P(LI)D & LKTGRAFTLIDP & LKASLAYLPFDV & \\
\hline A3 (core 2$)$ & LAYxxYTSG(ST)TGxPKG & LAYVLFTSGSTGEPKG & LAYVIFTSGSTGRPKG & \\
\hline A4 & FDxS & FDAC & FDAA & \\
\hline A5 & NxYGPTE & NGYGQSE & NAYGPTE & \\
\hline A6 (core 3) & GELxLxGxG(VL)ARGYL & GELVIESPGIARGYI & GELVVTGDGLARGYT & \\
\hline A7 (core 4$)$ & $\mathrm{Y}(\mathrm{RK}) \mathrm{TGDL}$ & YRTGDL & YRTGDR & \\
\hline A8 $($ core 5$)$ & GRxDxQVKIRGxRIELGEIE & GRRDSQVKIRGQRVTSEVE & GRMDQQVKIRGHRIELAEVE & \\
\hline A9 & LPxYM(IV)P & LPQHSIP & LPSYMIP & \\
\hline A10 & NGK(VL)DR & TGKTDR & SGKVDR & \\
\hline \multicolumn{5}{|l|}{ Thiolation } \\
\hline $\mathbf{T}($ core 6$)$ & DxFFxLGG(HD)S(LI) & ASFFELGGDSI & [T2]: DNFFKLGGHSL & \\
\hline \multicolumn{5}{|l|}{ Condensation } \\
\hline $\mathrm{C} 1$ & SxAQxR(LM)(WY)xL & TPFQSDVMDC & [C2]: SYAQGRIWFL & [C3]: YPATQMQRLF \\
\hline $\mathrm{C} 2$ & RHExLRTxF & RQTPALRTC & RHETLRTTF & QHFDMFRTV \\
\hline $\mathrm{C} 3$ & MHHxISDG(WY)xL & SHALVDNVLQE & MHHIISDGWSI & MSHALYDGIEL \\
\hline $\mathrm{C} 4$ & YxD(FY)AVW & NVQYANG & YRDFAVW & PPKFARY \\
\hline C5 & $(\mathrm{IV}) \mathrm{GxFVNT}(\mathrm{QL})(\sim) \mathrm{xR}$ & $\mathrm{ND}$ & IGFFVNTQCMR & VGPCTNTIPVR \\
\hline C6 & $(\mathrm{HN}) \mathrm{QD}(\mathrm{YV}) \mathrm{PFE}$ & HDDAMHE & HQDVPFE & MQDQYLD \\
\hline $\mathrm{C} 7$ & RDxSRNPL & RDVARFLR & RDTSRNPL & REDQLANE \\
\hline \multicolumn{5}{|l|}{$N$-Methylation } \\
\hline M1 (SAM) & $\mathrm{VL}(\mathrm{DE}) \mathrm{GxGxG}$ & & VLEIGTGSG & \\
\hline M2 & NELSxYRYxAV & & NELSAYRYAAV & \\
\hline M3 & VExSxARQxGxLD & & VEVSCARQWSQSG & \\
\hline \multicolumn{5}{|l|}{ Reductase } \\
\hline $\begin{array}{r}\mathrm{R} 1[\mathrm{NAD}(\mathrm{P}) \mathrm{H} \\
\text { binding site] }\end{array}$ & $\mathrm{V}(\mathrm{LF})(\mathrm{LV}) \mathrm{TG}(\mathrm{AV})(\mathrm{TN}) \mathrm{G}(\mathrm{YF}) \mathrm{LG}$ & & ILGVGNLGKFVA & \\
\hline $\mathbf{R} 2$ & VxxxVRA & & WDAAVKA & \\
\hline R3 & GDL & & VDL & \\
\hline R4 & VYPYxxLRx(PL)NVxxT & & VYPTSPFSIVHAGRG & \\
\hline R5 & GYxxSKWxx & & GYLALQGKRL & \\
\hline R6 & RPG & & $\mathrm{ND}$ & \\
\hline R7 & LExx(VI)GFLxxP & & IETLVNMVKQG & \\
\hline
\end{tabular}

fourth module of CssA of T. inflatum (50\%), and the leucine-activating domain of bacitracin synthetase (BacA) $(60 \%)$ (Table 2). However, chemical analysis of the nrpsxy gene product has now confirmed that the first A domain of NRPSXY is responsible for the activation of D-2-hydroxyisovaleric acid, while the second A domain activates $\mathrm{N}$ methylleucine.

Regarding the efxy gene, its deduced amino acid sequence was composed of 602 amino acids, and was interrupted by four introns of 63, 62, 58 and 64 bp in length. This protein sequence showed similarity to many membrane transport proteins of the MFS, including those from Bcmfs 1 of Botrytis cinerea (76\% similarity) (Hayashi et al., 2002), AflT of Aspergillus clavatus (68\% similarity), TOXA of Cochliobolus carbonum ( $56 \%$ similarity) (Pitkin et al., 1996) and the MFS multidrug transporter of A. fumigatus
AF293 (66\% similarity). Secondary structure analysis by TMHMM (http://www.cbs.dtu.dk/services/TMHMM) revealed that EFXY contained 14 membrane-spanning domains.

\section{Inactivation of the nrpsxy gene}

To determine the function of the gene, insertional mutagenesis of the nrpsxy gene was performed. To interrupt the nrpsxy gene in the chromosomal locus of Xylaria sp. BCC1067, we constructed a linear DNA disruption fragment in which a phleomycin-resistance cassette, ble, was inserted by blunt-end ligation in the SmaI site of nrpsxy flanked by $1.048 \mathrm{~kb}$ EcoRI/SmaI and $1.451 \mathrm{~kb}$ SmaI/EcoRI fragments of the nrpsxy gene (Fig. 3a). Transformation of Xylaria sp. BCC1067 with the linear DNA fragment and selection on phleomycin led to the 
Table 2. Signature sequences of amino acids in the putative activating domains of NRPSXY

Abbreviations: ESYN, enniatin synthetase; CssA, cyclosporin synthetase; BacA, bacitracin synthetase; SrfA, surfactin synthetase; PhsC, phosphinotricin synthetase; Ent, enterobactin synthetase; LicD, lichenycin synthetase; CDA, calcium-dependent antibiotic synthetase; Com, complestatin synthetase; HTS, HC-toxin synthetase. Bold or italic type indicates the closest resemblance of NRPSXY modules to others present in the databases.

\begin{tabular}{|c|c|c|c|c|c|c|c|c|c|c|c|}
\hline \multirow{2}{*}{ NRPS module } & \multirow{2}{*}{ Activated substrate (source) } & \multicolumn{10}{|c|}{ Amino acid residue at signature sequence position ${ }^{\star}$} \\
\hline & & 235 & 236 & 239 & 278 & 299 & 301 & 322 & 330 & 331 & 517 \\
\hline NRPSXY module 2 & N-Methylleucine (this work) & $D$ & $A$ & $W$ & $L$ & $V$ & $G$ & $A$ & $V$ & $M$ & $K \dagger$ \\
\hline ESYN module 1 & D-2-Hydroxyisovaleric acid & G & A & $\mathbf{L}$ & $\mathbf{H}$ & $\mathrm{V}$ & V & G & $\mathbf{I}$ & $\mathrm{C}$ & $\mathbf{K}$ \\
\hline ESYN module 2 & $N$-Methylvaline & $\mathrm{D}$ & G & $\mathrm{W}$ & $\mathrm{F}$ & I & G & I & I & I & $\mathrm{K} \dagger$ \\
\hline CssA module 4 & $N$-Methylvaline & $\mathrm{D}$ & A & $\mathrm{W}$ & M & $\mathrm{F}$ & A & $\mathrm{A}$ & I & $\mathrm{L}$ & $\mathrm{K} \dagger$ \\
\hline CssA module 9 & Valine & $\mathrm{D}$ & A & $\mathrm{W}$ & $\mathrm{M}$ & $\mathrm{F}$ & A & A & $\mathrm{V}$ & $\mathrm{M}$ & $\mathrm{K}$ \\
\hline BacA module 3 & Leucine & $\mathrm{D}$ & A & $\mathrm{W}$ & $\mathrm{F}$ & $\mathrm{L}$ & G & $\mathrm{N}$ & $\mathrm{V}$ & $\mathrm{V}$ & $\mathrm{K}$ \\
\hline SrfA module 2 & Leucine & $\mathrm{D}$ & A & $\mathrm{F}$ & M & $\mathrm{M}$ & G & $\mathrm{M}$ & $\mathrm{V}$ & $\mathrm{F}$ & $\mathrm{K}$ \\
\hline PhsC module 1 & Proline & $\mathrm{D}$ & $\mathrm{V}$ & $\mathrm{L}$ & $\mathrm{L}$ & $\mathrm{V}$ & A & G & $\mathrm{V}$ & $\mathrm{L}$ & $\mathrm{K}$ \\
\hline EntE module 1 & 2,3-Dihydroxybenzoate & $\mathrm{N}$ & $\mathrm{Y}$ & $\mathrm{S}$ & $\mathrm{A}$ & $\mathrm{Q}$ & G & Q & G & $\mathrm{L}$ & $\mathrm{K}$ \\
\hline
\end{tabular}

*The residues correspond to the gramicidin S synthetase PheA numbering (Stachelhaus et al., 1999).

$\dagger$ The $\mathrm{N}$-methylation domain is integrated in the adenylation domain between the motifs A8 and A9.

isolation of 14 transformants. All transformants were screened by PCR and Southern blot analysis to verify disruption of the nrpsxy locus (data not shown). Only one positive transformant (mutant NTT4) revealed disruption of the nrpsxy gene. Mutant NTT4 was identified on the basis of a band shift in the mutant and the absence of similar products in the wild-type (Fig. 3a). Insertion of the ble cassette into the nrpsxy gene was verified using primer pairs specific to the ble cassette (BleF and OliC) and the region of the nrpsxy gene flanking the insertion site $(\mathrm{OliC}+\mathrm{T} 3$ and $\mathrm{T} 10+\mathrm{BleF} ; \mathrm{T} 10$ and $\mathrm{T} 3$ are specific primers for the $5^{\prime}$ - and $3^{\prime}$-flanking regions of the integration site, respectively). These primer pairs produced specific products, suggesting that the nrpsxy gene was disrupted by ble cassette insertion. Amplification of genomic DNA from mutant NTT4 with a T6 + T7 primer pair generated a PCR product of $\sim 2.7 \mathrm{~kb}$, which may be compared to the nondisrupted size of genomic DNA from a wild-type strain, which generated a PCR product of $\sim 720 \mathrm{bp}$. OliC $+\mathrm{T} 3$ and $\mathrm{T} 10+$ BleF primer pairs showed PCR products of the predicted sizes of $\sim 1.9$ and $\sim 3.5 \mathrm{~kb}$, respectively (Fig. 3b), which were absent when amplified from genomic DNA from a wild-type strain. This result was confirmed by Southern blot analysis. DraI-digested genomic DNA from a wild-type strain and mutant NTT4 was hybridized to a $2.5 \mathrm{~kb}$ probe located at the $5^{\prime}$ end of the gene. A homologous crossover into the DraI fragment would yield bands of $\sim 4.5$ and $\sim 5.2 \mathrm{~kb}$ and the absence of the $3.1 \mathrm{~kb}$ wild-type band, as seen with mutant NTT4, indicating ble cassette insertion into the nrpsxy gene, as shown in Fig. 3(c).

\section{Identification of a substance encoded by the nrpsxy gene}

HPLC analysis of mycelium extracts from the wild-type was used as a reference in comparison to the mutant NTT4. The wild-type metabolic profile showed a visible peak related to substance $A$ at a retention time of $49.3 \mathrm{~min}$ (Fig. 4a), whereas this peak disappeared in the profile of mutant NTT4 under the same conditions (Fig. 4b). Substance A was detected in the wild-type by methanol extraction of mycelia of Xylaria sp. BCC1067 separated by Sephadex LH20 column chromatography and purified by HPLC. The structure of substance A was elucidated using spectroscopic methods, especially ${ }^{13} \mathrm{C}$ NMR, ${ }^{1} \mathrm{H}$ NMR and MS analysis. The ${ }^{1} \mathrm{H}$ NMR spectrum showed five $N$-methyl signals at 2.87, 2.90, 3.02, 3.06 and 3.27 p.p.m.; and the ${ }^{13} \mathrm{C}$ NMR spectrum in the same solvent revealed a total of 60 signals. The NMR spectra are shown in Supplementary Fig. $\mathrm{S} 1$ and the ${ }^{13} \mathrm{C}$ NMR spectra of substance $\mathrm{A}$ are summarized in Supplementary Table S1. The ESITOF mass spectra of substance A of $\mathrm{m} / z$ 931.5991 corresponded to $[\mathrm{M}+\mathrm{Na}]^{+}$(Supplementary Fig. S2), giving a molecular mass of 908.5991. HPLC analysis of its acid hydrolysate was performed using a chiral column. These analyses confirmed that substance A was a cyclodepsipeptide consisting of four residues of 2-D-hydroxyisovaleric acid (D-Hiv) and four residues of L-methylleucine ( $N$-Me-L-Leu). HPLC analysis of the acid hydrolysate of substance $A$ is shown in Supplementary Fig. S3. NMR spectra and mass analysis together with the amino acid composition are shown in Table 3. 
(a)

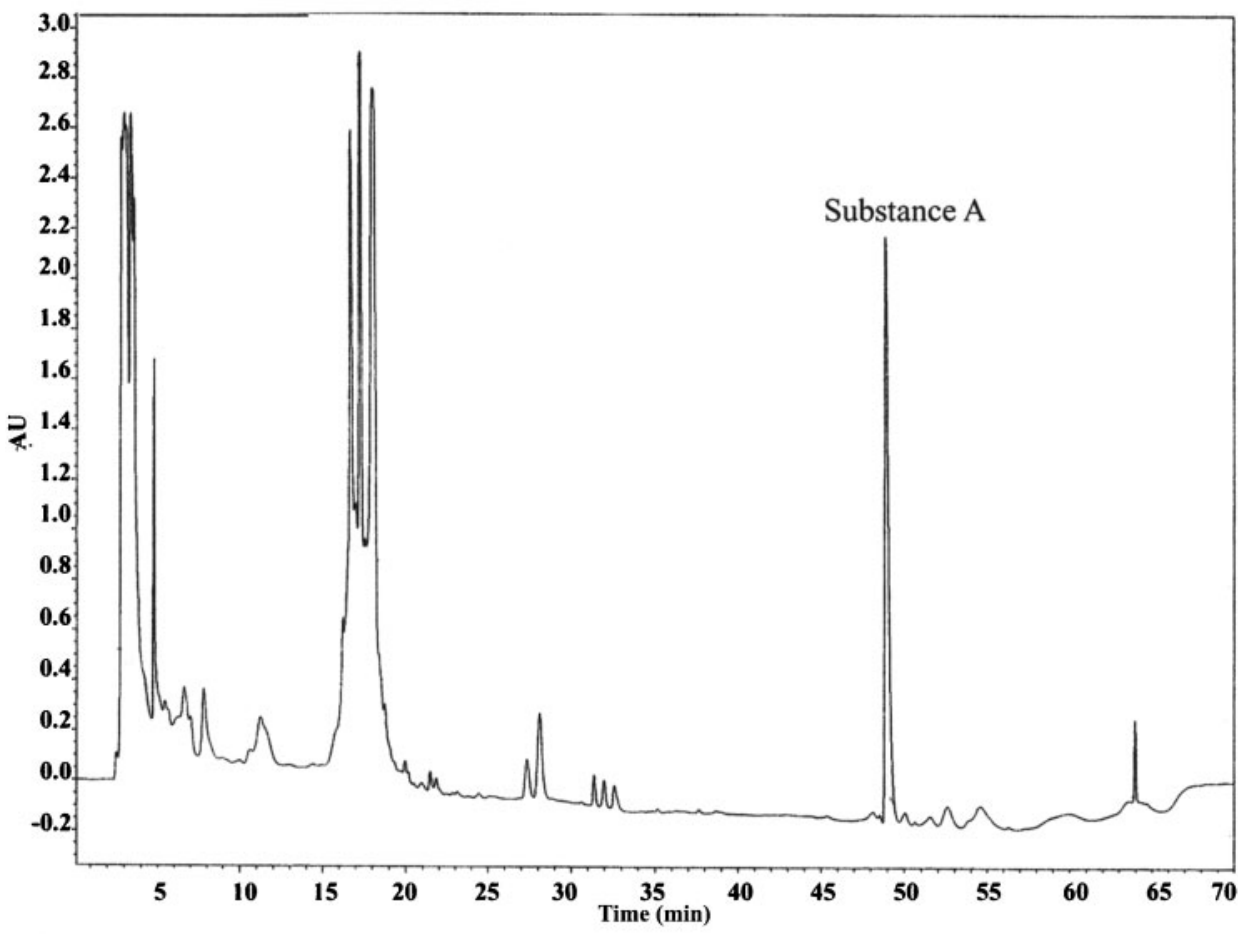

(b)

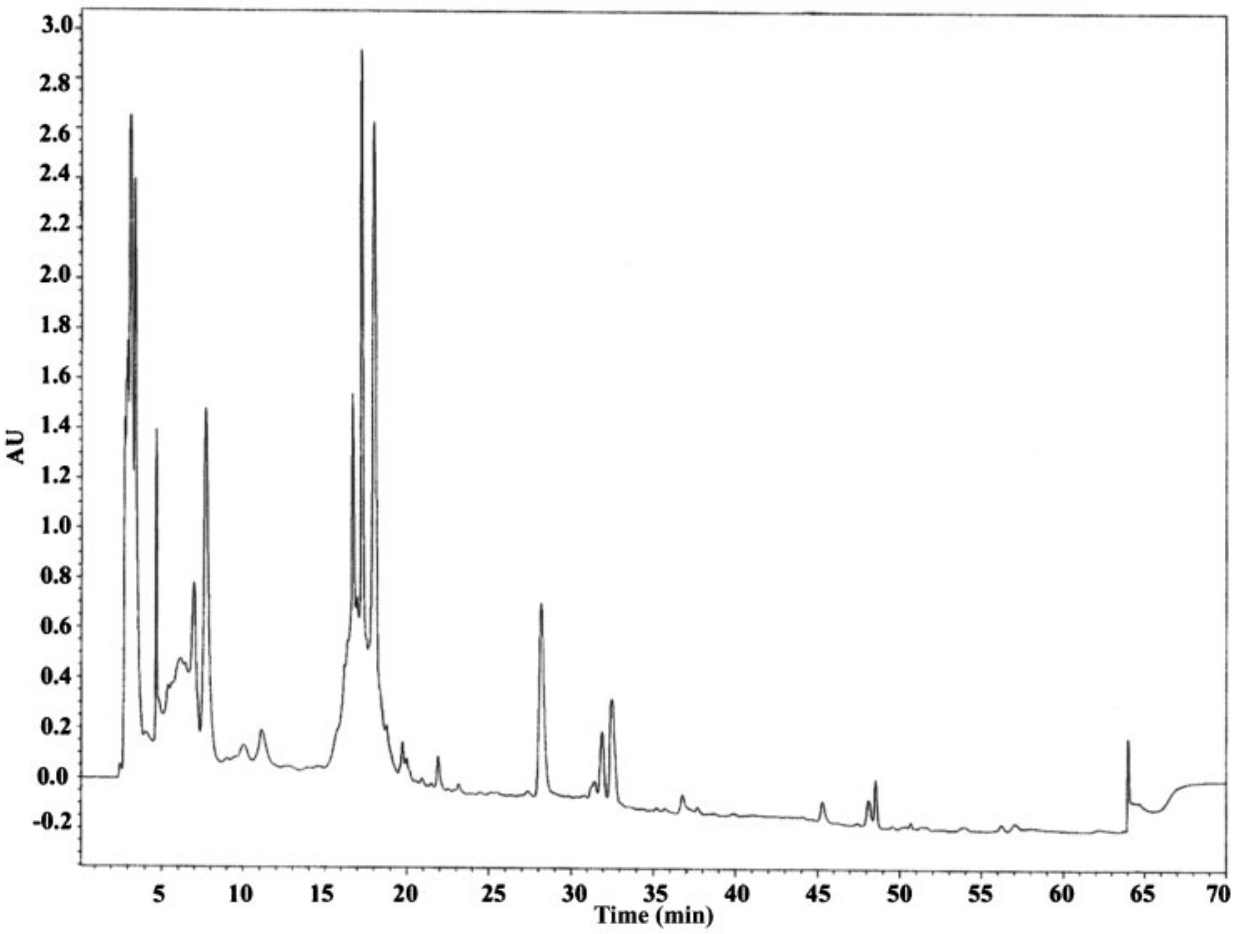

Fig. 4. HPLC chromatogram of methanol extracts from mycelia of Xylaria sp. BCC1067 wild-type and mutant NTT4 strains. (a) HPLC results from the wild-type extract are presented as a peak with retention time 49.3 min, designated the substance A peak. (b) The substance A peak is missing in extracts from mutant NTT4. (c) The extracts from mutant NTT4 were spiked with extracts from the wild-type. 
(c)

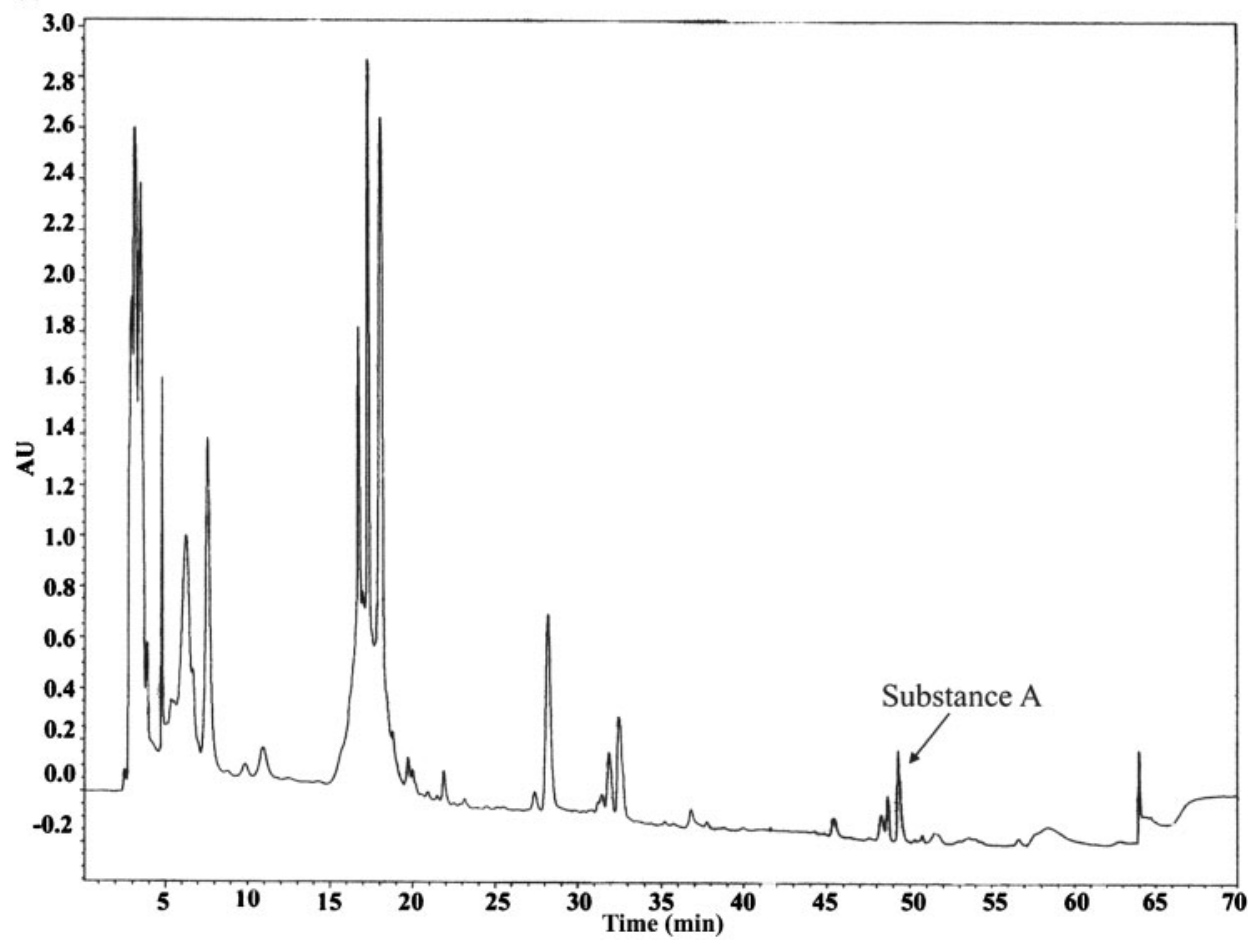

\section{Biological activities of substance A}

To evaluate the biological activity of substance A, pure substance A was subjected to several biological assays. The compound exhibited activity against $M$. tuberculosis H37Ra (MIC $6.25 \mu \mathrm{g} \mathrm{ml}^{-1}$ ), strongly inhibited proliferation of the human malaria parasite Pl. falciparum K1 $\left(\right.$ IC $_{50} 1.65 \mu \mathrm{g}$ $\mathrm{ml}^{-1}$ ), and also showed cytotoxic activity against Vero cells and three other cancer cell lines, KB, BC and NCI-H187 (Table 4). However, substance A exhibited no observable toxicity against the other tested bacteria.

\section{DISCUSSION}

Xylaria sp. BCC1067 has been shown to be a potential resource of bioactive secondary metabolites (Amnuaykanjanasin et al., 2005; Isaka et al., 2000). We have attempted to clone and analyse NRPS genes, which are expected to be involved in bioactive compound formation in Xylaria sp. BCC1067. In this study, we identified an NRPS gene, nrpsxy, and showed that disruption of this gene resulted in the elimination of substance A production. Structural elucidation of substance A was carried out by NMR and MS. Finally, confirmation by a literature data comparison indicated that the structure of substance A was a cyclodepsipeptide consisting of four D- $\alpha$-hydroxyisovaleryl-L- $N$-methylleucyl units, which was identical to bassianolide, a cyclooctadepsipeptide with a molecular formula of $\mathrm{C}_{48} \mathrm{H}_{84} \mathrm{~N}_{4} \mathrm{O}_{12}$, previously isolated from $B$. bassiana and $V$. lecanii (Suzuki et al., 1977). The results of gene disruption and metabolite structure elucidation confirmed the role of nrpsxy in the biosynthesis of an $\mathrm{N}$-methyl-cyclooctadepsipeptide, bassianolide.

The NRPS encoded by the nrpsxy gene is an enzyme consisting of a single polypeptide chain. Its domain architecture was found to be highly similar to that of $N$ methyl-cyclohexadepsipeptide enniatin synthetase (ESYN)

Table 3. Comparison of chemical characteristics of substance $A$ and bassianolide from Suzuki et al. (1977)

\begin{tabular}{|lcc|}
\hline Characteristic or analytical result & Substance A (this work) & Cyclodepsipeptide bassianolide (Suzuki et al., 1977) \\
\hline Molecular mass $(\mathrm{m} / \mathrm{z}$ ) & 908.5991 & 908 \\
Total signal in ${ }^{13} \mathrm{C}$ NMR spectrum & 60 & 60 \\
$N$-Methyl signal in ${ }^{1} \mathrm{H}$ NMR spectrum & Five $N$-methyl signals & Five $N$-methyl signals \\
(chemical shift in p.p.m.) & $(2.87,2.90,3.02,3.06$ and 3.27) & $(2.86,2.89,3.01,3.05$ and 3.25$)$ \\
Acid hydrolysis analysis & $N$-Methylleucine and & $N$-Methylleucine and \\
& D-hydroxyisovaleric acid & D-hydroxyisovaleric acid \\
\hline
\end{tabular}


Table 4. Antimycobacterial, antiplasmodial and cytotoxic activities of substance $A$

\begin{tabular}{|c|c|}
\hline Target cells & $\begin{array}{l}\text { Antimycobacterial, antiplasmodial or } \\
\left.\text { cytotoxic activity ( } \mu \mathrm{g} \mathrm{ml}^{-1}\right)\end{array}$ \\
\hline M. tuberculosis ${ }^{\star}$ (MIC) & 6.25 \\
\hline Pl. falciparum $\dagger\left(\mathrm{IC}_{50}\right)$ & 1.65 \\
\hline $\mathrm{KB}$ cells $\ddagger\left(\mathrm{IC}_{50}\right)$ & 3.64 \\
\hline $\mathrm{BC}$ cells $\ddagger\left(\mathrm{IC}_{50}\right)$ & 2.49 \\
\hline NCI-H187 cells $\ddagger\left(\mathrm{IC}_{50}\right)$ & 1.10 \\
\hline Vero cells $\ddagger\left(\mathrm{IC}_{50}\right)$ & 4.8 \\
\hline
\end{tabular}

${ }^{*}$ MIC values of the standard drugs rifampicin, kanamycin and isoniazide were $0.0047,2.5$ and $0.05 \mu \mathrm{g} \mathrm{ml}^{-1}$, respectively.

$\dagger$ The $\mathrm{IC}_{50}$ value of the standard antimalarial compound dihydroartemisinine was $3.9 \mathrm{nM}$.

$\ddagger \mathrm{IC}_{50}$ values of the standard compound ellipticine were $0.670 \mu \mathrm{g}$ $\mathrm{ml}^{-1}$ for KB cells, $0.129 \mu \mathrm{g} \mathrm{ml}^{-1}$ for BC cells, $0.273 \mu \mathrm{g} \mathrm{ml}^{-1}$ for NCI$\mathrm{H} 187$ cells and $0.5 \mu \mathrm{g} \mathrm{ml}^{-1}$ for Vero cells.

from Fusarium species (Haese et al., 1993, 1994). However, ESYN consists of two activation modules, which contain the catalytic binding sites for the substrates D-2-hydroxyisovaleric acid and the branched-chain L-amino acid, causing the substrates to assemble into three units of dipeptidol building blocks (von Döhren et al., 1997). It has been reported that the $N$-methylated cyclodepsipeptides beauvericin and PF1022A are synthesized by NRPSs that are probably of similar domain architecture to ESYN (von Döhren et al., 1997; Weckwerth et al., 2000).

The domain arrangement of NRPSXY revealed a distinct characteristic, which was composed of two tandem $\mathrm{T}$ domains at the C-terminal module. The presence of the second $\mathrm{T}$ domain possibly represents the waiting position for repeating the enzymic reaction. Based on the domain/ module organization of NRPSXY and the structure of substance $\mathrm{A}$, the hypothetical mechanism of bassianolide biosynthesis by Xylaria sp. BCC1067 can be postulated to resemble the biosynthesis mechanism of enniatin, beauvericin and PF1022A. It appears likely that NRPSXY use their modules or domains more than once in the assembly of a single product and could be categorized as an iterative NRPS, as is the case for enterobactin synthetase and gramicidin $S$ synthetase (von Döhren et al., 1997; Mootz et al., 2002).

The main difference between ESYN and NRPSXY is an additional putative KPR (EC 1.1.1.169) located at the Cterminal end of NRPSXY. Interestingly, in enniatin biosynthesis of Fusarium sambucinum, its 2-D-hydroxyisovaleric acid precursor is synthesized from 2-ketoisovalerate (2-KIV) catalysed by the D-hydroxyisovalerate dehydrogenase enzyme (Lee et al., 1992), and it has been reported that the KPR enzyme from Pseudomonas maltophilia 845 can catalyse the biosynthesis of 2-D-hydroxyisovaleric acid from 2-KIV as an alternative substrate (Shimizu et al., 1988). Furthermore, in the study of genes involved in AFtoxin biosynthesis in the plant-pathogenic fungus
Alternaria alternate, a gene designated AFTS1, which encodes a protein with similarity to enzymes of the aldoketoreductase superfamily, has been proposed to be the gene encoding an enzyme that catalyses the conversion of 2-KIV to 2-D-hydroxyisovaleric acid (Ito et al., 2004). For cereulide biosynthesis in $B$. cereus, it has been shown that the A domain of cereulide synthetase B peptide specifically activates the $\alpha$-keto acid (in this case 2-KIV), and is subsequently reduced to 2-D-hydroxyisovaleric acid by the keto-reductase domain embedded in its A domain before condensing to an adjacent amino acid precursor by the condensation domain (Magarvey et al., 2006). However, the function of the $\mathrm{R}$ domain at the $\mathrm{C}$-terminal of the NRPSXY peptide still warrants further analysis.

In conclusion, NRPSXY most resembles ESYN with respect to its domain organization. However, the end product of NRPSXY is a cyclooctadepsipeptide, a compound consisting of eight residues instead of the six residues synthesized by ESYN. In our case, comparative study of the amino acid specificity of the modules of NRPSXY, by predicting the signature sequence of the substrate-binding pocket together with chemical structure analysis of the NRPSXY product, revealed the specificity of 2-D-hydroxyisovaleric acid for the first A domain and of $\mathrm{N}$-methylleucine for the second A domain. These results confirmed the hypothesis proposed by Stachelhaus et al. (1999). This finding may be useful for future prediction of amino acid-activating domains and could help as a guide to the characterization of newly discovered NRPSs.

A second ORF, the efxy gene, was located $5.7 \mathrm{~kb}$ upstream of the nrpsxy gene. This gene putatively encodes a transporter protein of the MFS. These proteins are usually of a membrane-bound type that may help prevent accumulation of toxic compounds in cells (Hayashi et al., 2002). In filamentous fungi, a number of MFS transporters are known to mediate the secretion of endogenously produced toxins (Pitkin et al., 1996), including cercosporin, HC-toxin and trichothecenes. These MFS genes are located in gene clusters together with genes that encode the enzymes involved in the biosynthesis of these toxins (Hayashi et al., 2002; Pitkin et al., 1996). Therefore, the protein encoded by efxy may serve as an efflux pump that transports bassianolide out of the cells of Xylaria sp. BCC1067.

We report here what is believed to be the first evidence of a biosynthetic gene for the NRP bassianolide. In this study, we have shown an in vitro bioassay of substance $\mathrm{A}$, which exhibited antiplasmodial, antimycobacterial and antitumor activities beyond the previously reported insecticidal activity of bassianolide (Suzuki et al., 1977; Champlin \& Grula, 1979). These activities may be related to its cytotoxic actions; however, substance A showed no observable toxicity against bacteria such as Staph. aureus ATCC 29213, B. subtilis ATCC 6633, E. coli ACTT 25922 and Ps. aeruginosa ATCC 27853.

The potential of Xylaria sp. BCC1067 as a prolific resource for bioactive compounds has been demonstrated by 
chemical and genetic approaches, and future identification and characterization of new natural products are in the pipeline. We expect that using genetic knowledge as a basic tool for further modification of biosynthetic genes in this micro-organism will result in novel compounds with biotechnological value for medical, agricultural and industrial exploitation in the near future.

\section{ACKNOWLEDGEMENTS}

We thank Dr Masahiko Isaka for chemical identification of substance A (bassianolide). We also thank Dr Vanida Bhavakul for helpful discussion and suggestions, Dr Alongkorn Amnuaykanjanasin, Amporn Rungrod and Suranat Phonghanpot for their kind advice and support, and Pitchapa Berkaew for acid hydrolysis of substance A and HPLC analysis of the hydrolysate. This work was financially supported by a research grant from King Mongkut's University of Technology Thonburi.

\section{REFERENCES}

Amnuaykanjanasin, A., Punya, J., Paungmoung, P., Rungrod, A., Tachaleat, A., Pongpattanakitshote, S., Cheevadhanarak, S. \& Tanticharoen, M. (2005). Diversity of type I polyketide synthase genes in the wood-decay fungus Xylaria sp. BCC1067. FEMS Microbiol Lett 251, 125-136.

Brakhage, A. A. (1997). Molecular regulation of penicillin biosynthesis in Aspergillus (Emericella) nidulans. FEMS Microbiol Lett 148, 1-10.

Champlin, F. R. \& Grula, E. A. (1979). Noninvolvement of beauvericin in the entomopathogenicity of Beauveria bassiana. Appl Environ Microbiol 37, 1122-1126.

Cheevadhanarak, S., Renno, D. V., Saunders, G., Holt, G. \& Flegel, T. W. (1991). Cloning and overexpression of an alkaline proteaseencoding gene from Aspergillus oryzae with a dominant selectable marker. Gene 108, 151-155.

Cramer, R. A., Jr, Stajich, J. S., Yamanaka, Y., Dietrich, F. E., Steinbach, W. J. \& Perfect, J. R. (2006a). Phylogenomic analysis of non-ribosomal peptide synthetases in the genus Aspergillus. Gene $\mathbf{3 8 3}$ 24-32.

Cramer, R. A., Jr, Gamcsik, M. P., Brooking, R. M., Najvar, L. K., Kirkpatrick, W. R., Patterson, T. F., Balibar, C. J., Graybill, J. R., Perfect, J. R. \& other authors (2006b). Disruption of a nonribosomal peptide synthetase in Aspergillus fumigatus eliminates gliotoxin production. Eukaryot Cell 5, 972-980.

Haese, A., Schubert, M., Herrmann, M. \& Zocher, R. (1993). Molecular characterization of the enniatin synthetase gene encoding a multifunctional enzyme catalyzing $N$-methyldepsipeptide formation in Fusarium scirpi. Mol Microbiol 7, 905-914.

Haese, A., Pieper, R., Ostrowski, T. \& Zocher, R. (1994). Bacterial expression of catalytically active fragments of the multifunctional enzyme enniatin synthetase. J Mol Biol 243, 116-122.

Hayashi, K., Schoonbeek, H. J. \& De Waard, M. A. (2002). Bcmfsl, a novel major facilitator superfamily transporter from Botrytis cinerea, provides tolerance towards the natural toxic compounds camptothecin and cercosporin and towards fungicides. Appl Environ Microbiol 68, 4996-5004.

Hissen, A. H. T., Wan, A. N. C., Warwas, M. L., Pinto, L. J. \& Moore, M. M. (2005). The Aspergillus fumigatus siderophore biosynthetic gene sidA, encoding L-ornithine $N^{5}$-oxygenase, is required for virulence. Infect Immun 73, 5493-5503.
Isaka, M., Jaturaput, A., Kladwang, W., Punya, J., Lertwerawat, Y., Tanticharoen, M. \& Thebtaranonth, Y. (2000). Antiplasmodial compounds from the wood-decayed fungus Xylaria sp. BCC1067. Planta Med 66, 473-475.

Isaka, M., Palasarn, S., Sriklung, K. \& Kocharin, K. (2005). Cyclohexadepsipeptide from the insect pathogenic fungus Hirsutella nivea BCC 2594. J Nat Prod 68, 1680-1682.

Ito, K., Tanaka, T., Hatta, R., Yamamoto, M., Akimitsu, K. \& Tsuge, T. (2004). Dissection of the host range of the fungal plant pathogen Alternaria alternate by modification of secondary metabolism. Mol Microbiol 52, 399-411.

Keller, U. \& Schauwecker, F. (2003). Combinatorial biosynthesis of non-ribosomal peptides. Comb Chem High Throughput Screen 6, 527-540.

Konz, D. \& Marahiel, M. A. (1999). How do peptide synthetases generate structural diversity? Chem Biol 6, R39-R48.

Lee, C., Gorisch, H., Kleinkauf, H. \& Zocher, R. (1992). Highly specific D-hydroxyisovalerate dehydrogenase from the enniatin producer Fusarium sambucinum. J Biol Chem 267, 11741-11744.

Lee, B. N., Kroken, S., Chou, D. Y., Robbertse, B., Yoder, O. C. \& Turgeon, B. G. (2005). Functional analysis of all nonribosomal peptide synthetases in Cochliobolus heterostrophus reveals a factor, NPS6, involved in virulence and resistance to oxidative stress. Eukaryot Cell 4, 545-555.

Magarvey, N. A., Ehling-Schulz, M. \& Walsh, C. T. (2006). Characterization of the cereulide NRPS $\alpha$-hydroxy acid specifying modules: activation of $\alpha$-keto acids and chiral reduction on the assembly line. J Am Chem Soc 128, 10698-10699.

Marahiel, M. A., Stachelhaus, T. \& Mootz, H. D. (1997). Modular peptide synthetases involved in nonribosomal peptide synthesis. Chem Rev 97, 2651-2673.

McGaw, L. J., Jäger, A. K. \& van Staden, J. (2000). Antibacterial, anthelmintic and anti-amoebic activity in South African medicinal plants. J Ethnopharmacol 72, 247-263.

Mootz, H. D., Schwarzer, D. \& Marahiel, M. A. (2002). Ways of assembling complex natural products on modular nonribosomal peptide synthetases. ChemBioChem 3, 490-504.

Oide, S., Moeder, W., Krasnoff, S., Gibson, D., Haas, H., Yoshioka, K. \& Turgeon, B. G. (2006). NPS6, encoding a nonribosomal peptide synthetase involved in siderophore-mediated iron metabolism, is a conserved virulence determinant of plant pathogenic ascomycetes. Plant Cell 18, 2836-2853.

Paungmoung, P., Punya, J., Pongpattanakitshote, S., Jeamton, W., Vichisoonthonkul, T., Bhumiratana, S., Tanticharoen, M., Linne, U., Marahiel, M. U. \& Cheevadhanarak, S. (2007). Detection of nonribosomal peptide synthetase genes in Xylaria sp. BCC1067 and cloning of XyNRPSA. FEMS Microbiol Lett 274, 260-268.

Pitkin, J. W., Panaccione, D. G. \& Walton, J. D. (1996). A putative cyclic peptide efflux pump encoded by the TOXA gene of the plant-pathogenic fungus Cochliobolus carbonum. Microbiology 142, 1557-1565.

Raeder, U. \& Broda, P. (1985). Rapid preparation of DNA from filamentous fungi. Lett Appl Microbiol 1, 17-20.

Sarabia, F., Chammaa, S., Ruiz, A. S., Ortiz, L. M. \& Herrera, F. J. L. (2004). Chemistry and biology of cyclic depsipeptides of medicinal and biological interest. Curr Med Chem 11, 1309-1332.

Scherkenbeck, J., Jeschke, P. \& Harder, A. (2002). PF1022A and related cyclodepsipeptides - a novel class of anthelmintics. Curr Top Med Chem 2, 759-777.

Shimizu, S., Kataok, M., Chungs, C. M. \& Yamada, H. (1988). Ketopantoic acid reductase of Pseudomonas maltophilia 845. J Biol Chem 263, 12077-12084. 
Stachelhaus, T., Mootz, H. D. \& Marahiel, M. A. (1999). The specificity-conferring code of adenylation domains in nonribosomal peptide synthetases. Chem Biol 6, 493-505.

Stack, D., Neville, C. \& Doyle, S. (2007). Nonribosomal peptide synthesis in Aspergillus fumigatus and other fungi. Microbiology 153, 1297-1306.

Suzuki, A., Kanaoka, M., Isogai, A., Murakoshi, S., Ichinoe, M. \& Tamura, S. (1977). Bassianolide, a new insecticidal cyclodepsipeptide from Beauveria bassiana and Verticillium lecanii. Tetrahedron Lett 25, 2167-2170.

Tilburn, J., Scazzocchio, C, Taylor, G. G., Zabicky-Zissman, J. H., Lockington, R. A. \& Davies, R. W. (1983). Transformation by integration in Aspergillus nidulans. Gene 26, 205-221.

Tobiasen, C., Aahman, J., Ravnholt, K. S., Bjerrum, M. J., Grell, M. N. \& Giese, H. (2007). Nonribosomal peptide synthetase (NPS) genes in Fusarium graminearum, F. culmorum and F. pseudograminearium and identification of NPS2 as the producer of ferricrocin. Curr Genet 51, $43-58$.

Turgay, K. \& Marahiel, M. A. (1994). A general approach for identifying and cloning peptide synthetase genes. Pept Res 7, 238-241. von Döhren, H. \& Grafe, U. (1997). General aspects of secondary metabolism. In Biotechnology, vol. 7, Products of Secondary Metabolism, pp. 1-322. Edited by H.-J. Rehm \& G. Reed. Weinheim: Wiley-VCH.

von Döhren, H., Keller, U., Vater, J. \& Zocher, R. (1997). Multifunctional peptide synthetases. Chem Rev 97, 2675-2705.

Weber, G., Schorgendorfer, K., Schneider-Scherzer, E. \& Leitner, E. (1994). The peptide synthetase catalyzing cyclosporine production in Tolypocladium niveum is encoded by a giant 45.8-kilobase open reading frame. Curr Genet 26, 120-125.

Weckwerth, W., Miyamoto, K., linuma, K., Krause, M., Glinski, M., Storm, T., Bonse, G., Kleinkauf, H. \& Zocher, R. (2000). Biosynthesis of PF1022A and related cyclooctadepsipeptides. J Biol Chem 275, 17909-17915.

Woodcock, D.M., Crowther, P. J., Doherty, J., Jefferson, S., DeCruz, E., Weidner, M. N., Smith, S. S., Michael, M. Z. \& Graham, M. W. (1989). Quantitative evaluation of Escherichia coli host strain for tolerance to cytosine methylation in plasmid and phage recombinants. Nucleic Acids Res 17, 3469-3478.

Edited by: L. N. Glass 